\title{
WestVirginiaUniversity
}

THE RESEARCH REPOSITORY @ WVU

West Virginia Agricultural and Forestry Experiment

Davis College of Agriculture, Natural Resources

Station Bulletins

And Design

$1-1-1926$

\section{Varietal Experiments and First Generation Crosses in Corn}

Ralph John Garber

T. E. Odland

T. C. Mcllvaine

K.S. Quisenberry

Follow this and additional works at: https://researchrepository.wvu.edu/ wv_agricultural_and_forestry_experiment_station_bulletins

\section{Digital Commons Citation}

Garber, Ralph John; Odland, T. E.; McIlvaine, T. C.; and Quisenberry, K. S., "Varietal Experiments and First Generation Crosses in Corn" (1926). West Virginia Agricultural and Forestry Experiment Station Bulletins. 199.

https://researchrepository.wvu.edu/wv_agricultural_and_forestry_experiment_station_bulletins/199 @ WVU. It has been accepted for inclusion in West Virginia Agricultural and Forestry Experiment Station Bulletins by an authorized administrator of

The Research Repository@WVU. For more information, please contact ian.harmon@mail.wvu.edu. 


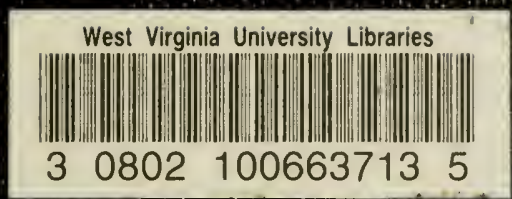




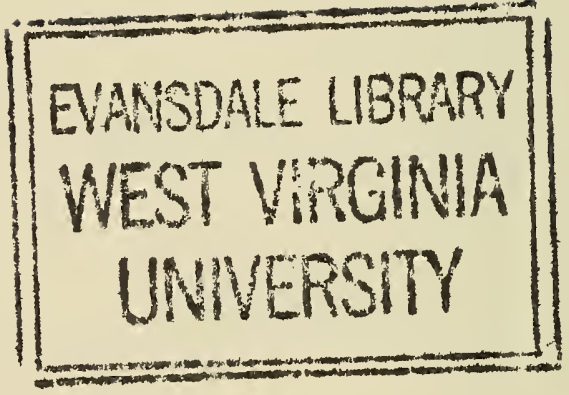


Restricted

Circulation Only

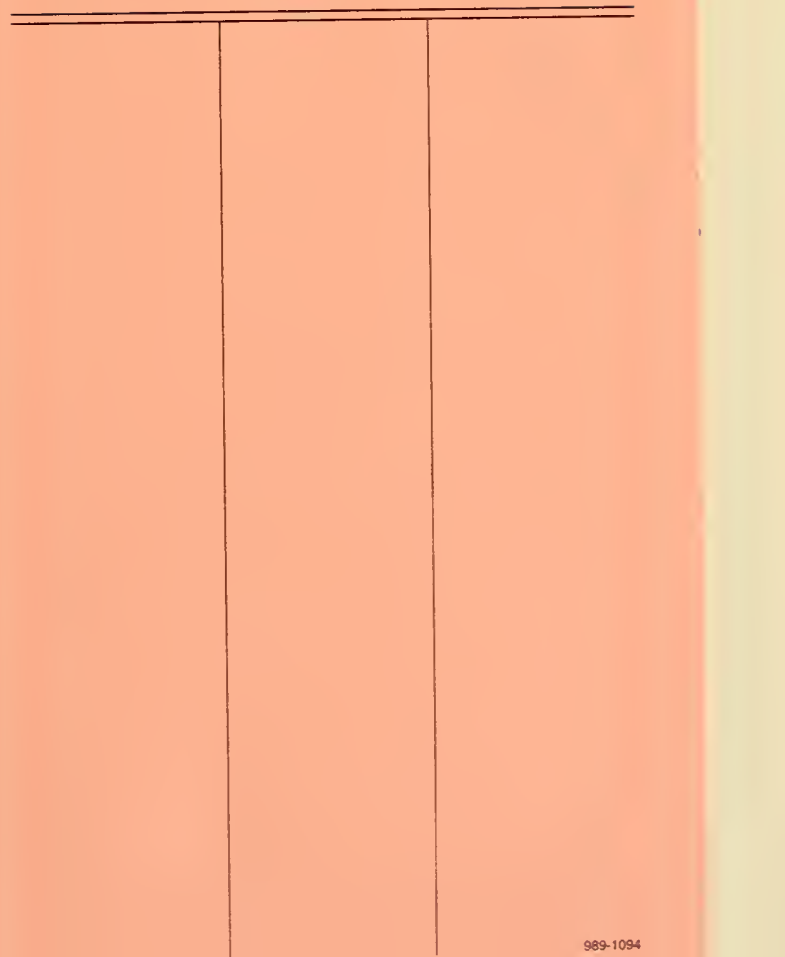





\section{Argicultural Experiment Station}

College of Agriculture, Tdest airginia Anibersity

HENRY G. KNIGHT, Director

Morgantown

\section{Varietal Experiments and First Generation Crosses in Corn}

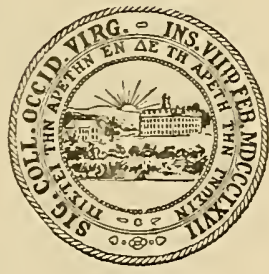

BY

R. J. GARBER, T. E. ODLAND,

K. S. QUISENBERRY, and T. C. MCILVAINE

Publications of this Station will be mailed free to any citizen of West Virginia upon written application. Address Director of the West Virginia Agricultural Experiment Station, Morgantown, W. Va. 


\section{AGRICULTURAL EXPERIMENT STATION STAFF}

FRANK BUTLER TROTTER, A. M., LL. D.

President of the University

GEORGE R. LYMAN, Ph. D.

Dean of the College of Agriculture

HENRY G. KNIGHT, Ph. D.

Director of the Experiment Station

WALTER C. SCHNOPP, B. S. Agr.

JOHN C. JOHNSTON

Agricultural Editor

\section{AGRONOMY}

R. J. Garber, Ph. D.

T. E. Odland, M. S.

Associate Agronomist

T. C. McIlvaine, Ph. D. $\dagger$

Assistant Agronomist

M. M. Hoover, M. S.

Junior Agronomist

H. K. Rowley, B. S. Agr.***

Seed Analyst

ANIMAL HUSBANDRY

E. A. Livesay, M. S.

Animal Husbandman

Chas. V. Wilson, M. S.

Aissistant Animal Husbandman

E. C. Stillwell, M. S.

Assistant Animal Husbandman

R. H. Tuckwiller, B. S. Agr.*

Assistant Animal Husbandman

\section{CHEMISTRY}

Henry G. Knight, Ph. D.

R. B. Dustman, Ph. D.

Chemist

Assistant Chemist

Chas. E. Weakley, Jr., B. A.

T. B. Leith, B. A.***

Assistant Chemist

T. J. Cochran, B. S.

Assistant Chemist

Junior Chemist

\section{DAIRY HUSBANDRY}

Ernest L. Anthony, M. S. Agr.

Dairy Husbandman

H. O. Henderson, M. S. Agr.

Associate Dairy Husbandman

Warren Gifford, B. S. Agr. $+\dagger$

Junior Dairy Husbandman

G. M. Trout, M. S.

Assistant in Dairy Husbandry

\section{ENTOMOLOGY}

L. M. Peairs, Ph. D.

W. E. Rumsey, B. S.**

Entomologist

State Entomologist
FARM ECONOMICS

A. J. Dadisman, Ph. D.

Paul A. Eke, Ph. D.

Farm Economist

Junior Farm Economist

F. D. Cornell, M. S.

Junior Farm Mechanician

W. W. Armentrout, M. S.

Junior Farm Economist

HOME ECONOMICS

Ruth Buchanan, Ph. D.

Home Economist

HORTICULTURE

M. J. Dorse 7, Ph. D.***

H. L. Crane, M. S. Agr.

Horticulturist

Associate Horticulturist

H. E. Knowlton, Ph. D.

Associate Horticulturist

K. C. Westover, M. S. Agr.

Assistant Horticulturist

Ernest Angelo, M. S. Agr.

Junior Horticulturist

L. F. Sutton, B. S. Agr.t

Asisistant Horticulturist

Troy M. Currence, B. S. Agr. $\dagger \dagger$

Assistant in Horticulture

PLANT PATHOLOGY

N. J. Giddings, Ph. D.

Anthony Berg, M. S.

Plant Pathologist

Assistant Plant Pathologist

L. H. Leonian, Ph. D.

Assistant Plant Pathologist

E. C. Sherwood, M. S.

Assistant Plant Pathologist

POULTRY HUSBANDRY

Horace Atwod, M. S. Agr.

Poultry Husbandman

E. P. Deatrick, Ph. D.

SOILS

Associate Soil Technologist

*In co-operation with the U. S. Department of Agriculture, Washington, D. C.

**In co-operation with the State Department of Agriculture, Charleston, W. Va.

***Resigned September 1, 1925 .

†In charge of the Maggie Sub-Station, Maggie, W. Va.

fIn charge of the Reymann Memorial Farms, Wardensville, W. Va.

tron leave of absence. 


\section{Varietal Experiments and First Generation Crosses in Corn}

Corn is the most important cultivated crop from the standpoint of both acreage and value grown in West Virginia. Approximately one-fourth of the total area under cultivation in this state is used for the production of this crop. During the last five years there have been planted annually within the state, approximately 600,000 acres of corn with an average yield of about 34 bushels per acre. The estimates of the United States Department of Agriculture and the Fourteenth Census of the United States show that the acreage of corn has been reduced somewhat during the last fifteen years. In 1909 there were 676,311 acres of corn harvested as compared with 568,219 acres in 1919.

The value of the corn crop in West Virginia is far greater than the value of any other field crop grown within the state. The value of corn compared with the values of four other crops is shown in Table I.

TABLE I.-The Monetary Value of Corn, Oats, Wheat, Cultivated Grasses for Hay, and Tobacco Grown in West Virginia in 1909 and 1919.*

\begin{tabular}{|c|c|c|}
\hline \multirow[t]{2}{*}{ Crop } & \multicolumn{2}{|c|}{ Value } \\
\hline & 1909 & 1919 \\
\hline$\overline{\text { Corn }}$ & $\$ 11,907,261$ & $\$ 29,768,131$ \\
\hline Cultivated grasses for hay & $7,318,162$ & $18,334,421$ \\
\hline Wheat …- & $2,697,141$ & $8,395,097$ \\
\hline Oats & $\begin{array}{r}912,388 \\
1923180\end{array}$ & $3,054,668$ \\
\hline - & & \\
\hline
\end{tabular}

*From the Fourteenth Census of the United States.

The cultivated grasses listed in Table I consist largely of timothy and red clover grown alone and in mixtures. In 1909 the value of the corn crop was slightly more than one third, and in 1919 somewhat less than one third, the total value of all field and horticultural crops grown within the state during the two years respectively. 
Most of the corn produced in West Virginia is grown in the western half of the state, particularly along the Ohio River. The section known as the Eastern Panhandle and the south eastern section of the state also produce considerable corn. The ten leading counties in the production of this crop are, in the order named: Jefferson, Wayne, Jackson, Berkeley, Mason, Marshall, Greenbrier, Lincoln, Braxton, and Roane.

\section{OBJECTS OF EXPERIMENTS}

One of the requirements for successful corn production is the selection of a variety best adapted to the particular conditions of soil and climate in which the crop is to be grown. With the aim of aiding the farmer in determining what varieties best meet his needs, the Department of Agronomy of the West Virginia Agricultural Experiment Station, in 1921 and 1922, started rather extensive varietal tests. Most of these tests have been carried on cooperatively in various sections of the state.* In addition to the cooperative experiments, varietal trials have been carried out on the Agronomy Farm and at the Maggie Substation.

In the cooperative experiments and in the experiments at the Maggie Substation, the main object was to compare the different varieties on the basis of yield of shelled corn per acre, whereas the varieties grown on the Agronomy Farm were compared from the standpoint of both yield of shelled corn and yield of forage (silage) per acre.

Another object of the varietal experiments was to compare the value of home grown seed with seed from some other source. Among the varieties grown on the Agronomy Farm were two commonly used as silage corn, which afforded an opportunity to make comparison between locally grown grain varieties and introduced silage varieties. In this experiment a variety of sunflowers also was grown for the purpose of making comparisons on the basis of yield of forage.

*The authors desire to acknowledge their indebtedness to the following persons who helped make the cooperative tests possible: D. R. Dodd, Extension Agronomy Specialist; R. M. Musser, County Agent, Greenbrier County; J. E. Romine, County Agent. Randolph County; C. G. Degen, County Agent, Berkeley County; W. H. Roberts, County Agent, Mercer County; E. G. Hibbs, County Agent, Brooke County; L. F. Sutton, Superintendent Reymann Memorial Farms; J. B. Sydenstricker; C. F. Hammond; A. H. Stuckey; J. A. Godfrey; O. B. Humphreys; O. H. Bowling; P. E. Wheeler; W. H. Sill; Will Finley ; and L. J. Belcher. 
In addition to the varieties, certain first generation crosses between varieties were included in the experiments in order to determine their relative value compared with that of the parents, particularly from the standpoint of yield and number of days required to mature. At the higher altitudes in West Virginia, the number of days required for maturity is a limiting factor in the production of corn. It was thought that first generation crosses between an early maturing flint corn and somewhat later maturing dent varieties might prove of value under these conditions.

\section{METHODS USED IN EXPERIMENTS}

Owing to the limited area of land available on the Agronomy Farm the experiments here were carried out on smaller plots than at the other places. Each variety was grown in three systematically distributed plots, each one of which consisted of four rows approximately 136 feet long and 3 feet and 6 inches apart. One-half of each plot (divided transversely) was planted in hills 3 feet and 6 inches apart, and the other half was planted in drilled rows with the plants 15 inches apart in the rows. An excess of seed was planted and when the corn was about six inches high it was thinned to two stalks per hill and to a single stalk in the drilled rows.

Notes were taken on average height of plant and days to maturity, and previous to harvesting a note was taken on the stand. No attempt was made to correct yield because of missing stalks or hills, but if a plot showed a relatively high percentage of missing plants it was eliminated or if the missing plants occurred mostly in a certain part of the plot that part only was eliminated. In general, the stand of corn obtained by the method outlined above was uniform and there were relatively few missing plants in the test plots.

The yield of each variety was based on the two inner rows (end plants were discarded) of each plot except where otherwise noted. The yield of forage was determined from the drilled rows and the yield of shelled corn from the rows planted by the hill method. A variety was considered sufficiently matured for the silo when the ears reached the "glazed stage" and at this time the two inner drilled rows of each plot were cut, weighed, and a sample taken for the determination of yield on an air-dry basis. A portion of the sample which previously had been run through a feed cutter was firmly tamped into two-quart Mason jars and later analyzed. Samples preserved in this way produced very satisfactory silage. 
The yield of shelled corn per acre was based on that part of the plot planted by the hill method. When the two central rows of each plot were mature they were cut and shocked and later in the fall (late October or November) the corn was husked, weighed and a sample taken for the determination of percentage of moisture and the relative amount of shelled corn. In 1921 and 1922 yield was computed on the basis of air-dry shelled corn per acre and in 1923 and 1924 on the basis of shelled corn containing 14 per cent moisture.

The cooperative varietal experiments and the experiments at Maggie were carried on in a manner similar to that used on the Agronomy Farm except with regard to size of plots and number of replications. In general each plot consisted of four rows approximately 136 feet long and 3 feet and 6 inches apart. The corn was planted in hills 3 feet and 6 inches each way and thinned to two stalks per hill. Each variety was grown in four systematically distributed plots and the yield was determined on the basis of bushels of shelled corn per acre. A representative of the Agronomy Department was on hand to help plant the cooperative tests and again later to help husk, wergh, and sample the corn. The percentage of moisture and relative amount of shelled corn were determined at Morgantown. In case the above plan was not followed, a note explaining the particular procedure followed was made.

\section{SOURCE OF SEED}

The seed used in the varietal trials reported here was obtained from various places. In some cases the seed was obtained from the same original source each year and in other cases the seed had been produced on or near the Agronomy Farm since its original introduction. In the cooperative tests seed of the local varieties was obtained in the vicinity of the test and in most cases from the same source each year. In Table II. are listed the varieties (except the local varieties in the cooperative tests) together with the source of the seed used each year in the several varietal trials. 
TABLE II.-Varieties and the Source of Seed Used in the Corn Varietal Experiments.

\begin{tabular}{|c|c|c|c|c|}
\hline \multirow{2}{*}{ Varieties } & \multicolumn{4}{|c|}{ Source of Seed for Each Year } \\
\hline & 1921 & 1922 & 1923 & 1924 \\
\hline $\begin{array}{l}\text { Boone County } \\
\text { White }\end{array}$ & $\begin{array}{l}\text { Funk Bros. Seed Co. } \\
\text { Bloomington, Ill. }\end{array}$ & Same as 1921 & $\begin{array}{l}\text { Agronomy } \\
\text { Farm }\end{array}$ & $\begin{array}{r}\text { Same as } \\
1923\end{array}$ \\
\hline Blue Ridge & $\begin{array}{l}\text { W. H. Turner \& Son } \\
\text { Afton, Virginia }\end{array}$ & Same as 1921 & $\begin{array}{r}\text { Same as } \\
1921\end{array}$ & $\begin{array}{r}\text { Same as } \\
1921\end{array}$ \\
\hline Clarage & $\begin{array}{l}\text { F. E. Eichelberger } \\
\text { Washington Court } \\
\text { House, O. }\end{array}$ & $\begin{array}{l}\text { Agronomy } \\
\text { Farm }\end{array}$ & $\begin{array}{r}\text { Same as } \\
1922\end{array}$ & $\begin{array}{r}\text { Same as } \\
1922\end{array}$ \\
\hline Cocke's Prolific & $\begin{array}{l}\text { T. W. Wood \& Sons } \\
\text { Richmond, Va. }\end{array}$ & $\begin{array}{l}\text { John Lewis } \\
\text { Buckhannon, } \\
\text { W. Va. }\end{array}$ & $\begin{array}{l}\text { T. W. Wood } \\
\& \text { Sons } \\
\text { Richmond, } \\
\text { Va. }\end{array}$ & $\begin{array}{r}\text { Same as } \\
1923\end{array}$ \\
\hline Golden Glow & $\begin{array}{l}\text { Jippa Wielinga } \\
\text { Midway, Wis. }\end{array}$ & $\begin{array}{l}\text { Agronomy } \\
\text { Farm }\end{array}$ & $\begin{array}{r}\text { Same as } \\
1922\end{array}$ & $\begin{array}{r}\text { Same as } \\
1922\end{array}$ \\
\hline $\begin{array}{l}\text { Johnson County } \\
\text { White }\end{array}$ & & $\begin{array}{l}\text { C. E. Troyer } \\
\text { La Fontaine, } \\
\text { Ind. }\end{array}$ & $\begin{array}{l}\text { Agronomy } \\
\text { Farm }\end{array}$ & $\begin{array}{r}\text { Same as } \\
1923\end{array}$ \\
\hline Leaming & $\begin{array}{l}\text { Geo. S. Strosnider } \\
\text { Waynesburg, Pa. }\end{array}$ & Same as 1921 & $\begin{array}{r}\text { Same as } \\
1921\end{array}$ & $\begin{array}{r}\text { Same as } \\
1921\end{array}$ \\
\hline Longfellow & $\begin{array}{l}\text { R. Keeler } \\
\text { Bridgewater, Conn. }\end{array}$ & $\begin{array}{l}\text { Agronomy } \\
\text { Farm }\end{array}$ & $\begin{array}{l}\text { R. Keeler } \\
\text { Bridge- } \\
\text { water, Conn. }\end{array}$ & $\begin{array}{l}\text { Agronomy } \\
\text { Farm }\end{array}$ \\
\hline Knight's White & $\begin{array}{l}\text { L. N. Knight } \\
\text { Maggie, W. Va. }\end{array}$ & Same as 1921 & $\begin{array}{r}\text { Same as } \\
1921\end{array}$ & $\begin{array}{c}\text { Agronomy } \\
\text { Farm }\end{array}$ \\
\hline Silver King & & $\begin{array}{l}\text { Va. Exp. Sta. } \\
\text { Blacksburg, } \\
\text { Va. }\end{array}$ & $\begin{array}{r}\text { Same as } \\
1922\end{array}$ & $\begin{array}{r}\text { Same as } \\
1922\end{array}$ \\
\hline $\begin{array}{l}\text { Woodburn White } \\
\text { Dent } \\
\text { U. S. Selection } \\
\text { No. } 77\end{array}$ & & $\begin{array}{l}\text { J. M. Brown } \\
\text { Piketon, O. }\end{array}$ & $\begin{array}{r}\text { Same as } \\
1922\end{array}$ & $\begin{array}{r}\text { Same as } \\
1922\end{array}$ \\
\hline $\begin{array}{l}\text { Reid's Yellow } \\
\text { Dent }\end{array}$ & $\begin{array}{l}\text { Funk Bros. Seed Co. } \\
\text { Bloomington, Ill. }\end{array}$ & Same as 1921 & $\begin{array}{l}\text { Agronomy } \\
\text { Farm }\end{array}$ & $\begin{array}{r}\text { Same as } \\
1923\end{array}$ \\
\hline Minnesota No. 13 & & $\begin{array}{l}\text { Univ. Farm } \\
\text { St. Paul, Minn. }\end{array}$ & Same as & $\begin{array}{r}\text { Same as } \\
1922\end{array}$ \\
\hline $\begin{array}{l}\text { Mammoth Rus- } \\
\text { sian Sunflowers }\end{array}$ & $\begin{array}{l}\text { T. W. Wood \& Sons } \\
\text { Richmond, Va. }\end{array}$ & $\begin{array}{l}\text { Agronomy } \\
\text { Farm }\end{array}$ & $\begin{array}{r}\text { Same as } \\
1922\end{array}$ & $\begin{array}{r}\text { Same as } \\
1922\end{array}$ \\
\hline
\end{tabular}


The varieties Blue Ridge and Cocke's Prolific were included in the tests to represent the silage type of corn. "The other varieties listed in Table II are dent varieties with the exception of Longfeliow which is a flint corn. The Mammoth Russian variety of sunflowers is also included in Table II. Knight's White is a large-eared, white dent corn that has been grown in the neighborhood of Maggie, West Virginia for a number of years. In that locality it is frequently used as a silage corn. Woodburn White Dent or U. S. Selection No. 77 is a relatively new variety of corn developed by the United States Department of Agriculture.

The crossed seed for the first generation crosses was produced on an isolated plot on the Agronomy Farm. The several dent varieties were grown in alternate rows with Longfellow Flint; the former being detasseled. In this way the dent varieties were prevented from forming pollen and the ears produced by them were the result of cross-pollination with Longfellow Flint.

\section{EXPERIMENTS AT MORGANTOWN}

In Table III are listed the varieties of corn, first generation crosses, and Mammoth Russian sunflowers included in the varietal experiments on the Agronomy Farm. In this Table the average number of days to maturity, average height, and average yield in bushels of shelled corn per acre are shown.

An examination of the second column of Table III shows that Woodburn White Dent, Knight's White, Cocke's Prolific, Johnson County White, Boone County White, and Blue Ridge are relatively late maturing varieties. Longfellow, the only flint corn in the test, is by far the earliest maturing variety. The other varieties of corn and first generation crosses range in average number of days to 1nature from 147 to 151 days. Sunflowers mature somewhat later than Longfellow flint corn.

It is interesting to compare the first generation crosses with the dent parents. Reid's Yellow Dent crossed with Longfellow flint matured on the average 4 days earlier; Boone County White with Longfellow 7 days earlier; Blue Ridge with Longfellow 7 days earlier; and Cocke's Prolific with Longfellow 11 days earlier than their respective dent parents. 


\section{TABLE III-_Yield in Bushels of Shelled Corn Together With Height, and Days to Mature, of Corn Varieties Grown on the Agronomy Farm.}

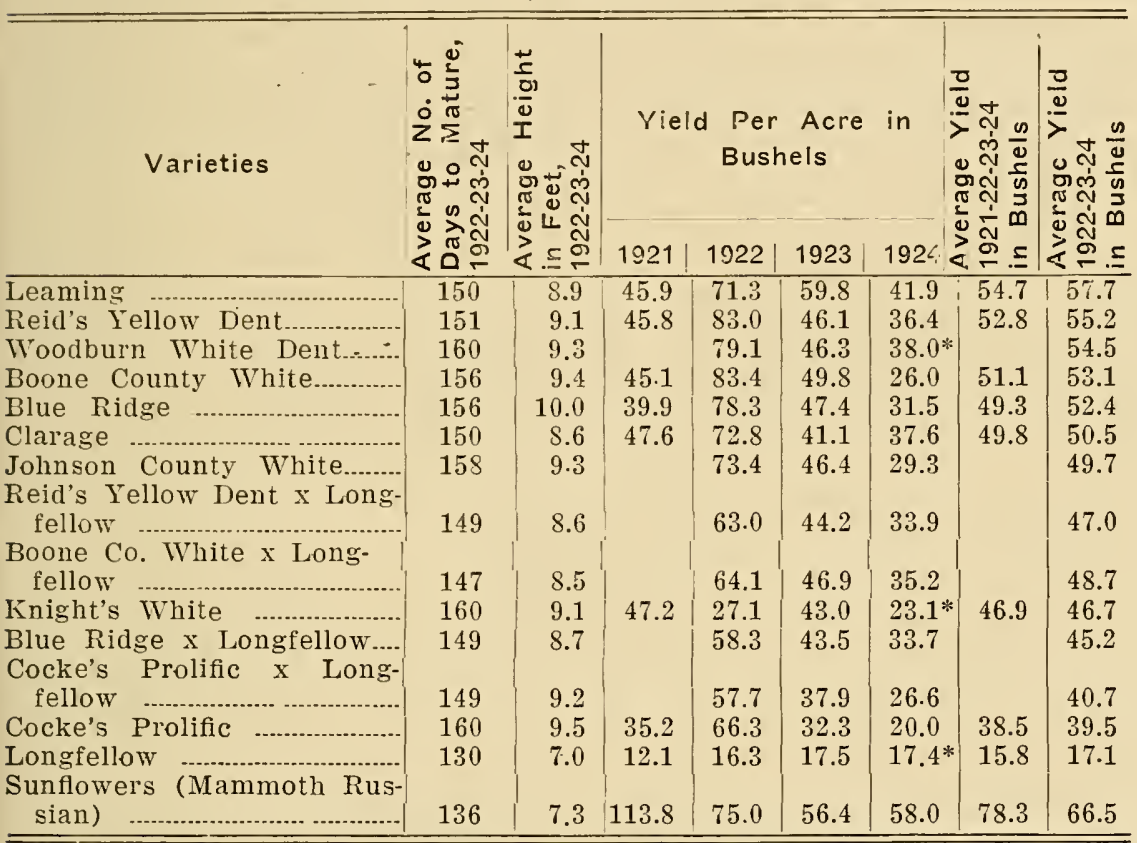

*Yield in 1924 based on the average of two plots oniy.

With regard to average height most of the varieties range from 8.5 feet to 9.5 feet. The average height of the tallest variety, Blue Kidge, was 10 feet and that of the shortest variety, Longfellow, was 7 feet. The first generation crosses were on the average somewhat shorter than their respective dent parents.

In the last column of Table III the average yields in bushels of shelled corn per acre of the several varieties grown during the three years 1922 to 1924 inclusive are tabulated. Some of the varieties were grown also in 1921. The average yields of these varieties for four years are listed in next to the last column of the table.

In interpreting yield data such as are presented in Table III it is necessary to take into consideration not only the averages but also the variability of the yields throughout the entire period of the experiment. For example, considering the two varieties which rank first and second in yield from the standpoint of both three-year and four-year averages, it is evident that in 1921 the yields of the two varieties were practically identical, in 1922 Reid's Yellow Dent exceeded Leaming by 11.7 bushels and in 1923 and 1924 Leaming 
Exceeded Reid's Yellow Dent by 13.7, and 5.5 bushels during the two years respectively. It is possible to apply a mathematical method of analysis to data such as these and determine the significance of the difference between the average yields. The method is briefly discussed at the end of this bulletin in the appendix. It suffices here to state that when the data on yield of these two varieties are so analyzed, the difference between their average yields is found to be not significant. In other words, should the above experiment be repeated under similar circumstances it would occasion no surprise if in this second experiment the average yield of Reid's Yellow Dent exceeded that of Leaming. It is reasonable to expect that the more consistent the difference in yield between varieties throughout a period of years and the greater the difference between their average yields, the more significant the difference becomes: With the foregoing considerations in mind it is obvious that one may state with a greater degree of certainty, that under the given conditions the three or four highest yielding varieties are superior in yielding capacity to the three or four next highest yielding varieties, than that Leaming possesses greater yielding capacity than Reid's Yellow Dent. The yield data of Table III as well as those contained in subsequent tables are interpreted from this viewpoint.

The four varieties grown on the Agronomy Farm which produced the highest average yield of shelled corn per acre are Leaming, Reid's Yellow Dent, Woodburn White Dent, and Boone County White. Knight's White produced a relatively low average yield primarily because of the unfavorable growing conditions, particularly for late maturing varieties, in 1924. Of the late maturing varieties the yielding ability of Woodburn White Dent seems to have been affected least by the adverse conditions of 1924. Longfellow flint corn has been a low yielder consistently throughout the duration of the experiment. Mammoth Russian sunflowers yielded an average of 78.3 bushels (20 pounds per bushel) for the four-year period.

The average yields of the first generation crosses are considerably higher than the average yield of the Longfellow parent but somewhat lower (with one exception) than their respective dent parents. The average yield (as given in the last column of Table III) of Reid's Yellow Dent crossed with Longfellow is 6.5 bushels; of Boone County White with Longfellow 6.1 bushels; and of Blue Ridge with Longfellow, 7.2 bushels less than that of their respective dent parents. The average yield of Cocke's Prolific and Cocke's Prolific crossed with Longfellow are not very different. In general 
the first generation crosses tended to yield less but matured somewhat earlier than their respective dent parents.

In order to make further comparisons between the first generation crosses and their parents, certain measurements were made on random samples of ears taken from the crop grown in 1922. The characters considered were length of ear, circumference of ear at about one-third of the distance from the base to the tip and the number of rows of kernels per ear. The data are presented in Table IV.

TABLE IV.-The Average Length, Average Circumference, and Average Number of Rows of Kernels of Ears of Corn Taken at Random From Certain First Generation Crosses and Their Parents Grown in 1922.

\begin{tabular}{|c|c|c|c|c|}
\hline Varieties & $\begin{array}{l}\text { Number } \\
\text { of Ears } \\
\text { Consid- } \\
\text { ered }\end{array}$ & $\begin{array}{l}\text { Average } \\
\text { Length in } \\
\text { Inches }\end{array}$ & $\begin{array}{l}\text { Average } \\
\text { Circumfer- } \\
\text { ence in } \\
\text { Inches }\end{array}$ & $\begin{array}{l}\text { Number } \\
\text { of Rows } \\
\text { of Kernels }\end{array}$ \\
\hline Boone County White & 107 & $8.86 \pm 0.10$ & $7.13 \pm 0.04$ & $16.86 \pm 0.16$ \\
\hline Boone Co. White x Longfellow.. & 111 & $9.42 \pm 0.11$ & $5.93 \pm 0.03$ & $11.77 \pm 0.11$ \\
\hline Blue Ridge & 122 & $8.29 \pm 0.08$ & $7.05 \pm 0.03$ & $12.23 \pm 0.10$ \\
\hline Blue Ridge $\mathrm{x}$ Longfellow. & 115 & $9.04 \pm 0.09$ & $5.95 \pm 0.03$ & $10.40 \pm 0.10$ \\
\hline Cocke's Prolific .............. & 153 & $8.45 \pm 0.07$ & $5.39 \pm 0.02$ & $11.06 \pm 0.09$ \\
\hline Cocke's Prolific x Longfellow. & 134 & $9.56 \pm 0.11$ & $5.37 \pm 0.02$ & $9.81 \pm 0.09$ \\
\hline Reid's Yellow Dent & 104 & $8.75 \pm 0.08$ & $6.70 \pm 0.03$ & $17.29 \pm 0.14$ \\
\hline Reid's Yellow Dent x Longfellow & 111 & $9.63 \pm 0.10$ & $5.75 \pm 0.03$ & $11.86 \pm 0.12$ \\
\hline Longfellow & 40 & $9.52 \pm 0.17$ & $4.78 \pm 0.04$ & $8.00 \pm 0.00$ \\
\hline
\end{tabular}

An examination of the third column of Table IV shows that with regard to average length of ears the first generation crosses approached more closely to Longfellow, the flint parent, than to their respective dent parents. In no case is the difference between the average length of ears of a first generation cross and its flint parent significant. With regard to average circumference of ears (fourth column) the first generation crosses, with one exception, occupy a position midway between their respective parents. The average circumference of ears of Cocke's Prolific crossed with Longfellow does not differ significantly from that of Cocke's Prolific. In the average number of rows of kernels per ear (fifth column) also the first generation crosses occupy an intermediate position between their respective parents.

The yield in tons per acre of green and air dry forage and the average number of days from planting until harvest for each variety and each first generation cross may be found in Table $V$. The 
harvesting was done when the ears reached the "glazed stage," the usual time of cutting for the silo. The sunflowers were cut at the hard dough stage.

It may be seen from the second column of Table $V$ that Cocke's Prolific, Woodburn White Dent, Knight's White, and Johnson County White were latest in maturing and that Blue Ridge and Boone County White were next. It will be observed that these varieties also were the highest yielding sorts in the experiment. Longfellow flint corn and Mammoth Russian sunflowers matured first. In general the first generation crosses were ready for the silo considerably earlier than the dent parents. Cocke's Prolific crossed with Longfellow matured on the average 12 days; Boone County White with Longfellow 13 days; Reid's Yellow Dent with Longfellow 7 days; and Blue Ridge with Longfellow 13 days earlier than their respective dent parents. It is interesting to note that in general the difference is greater between the first generation crosses and the dent parents with regard to the growing period for silage than it is with regard to the growing period for grain. 


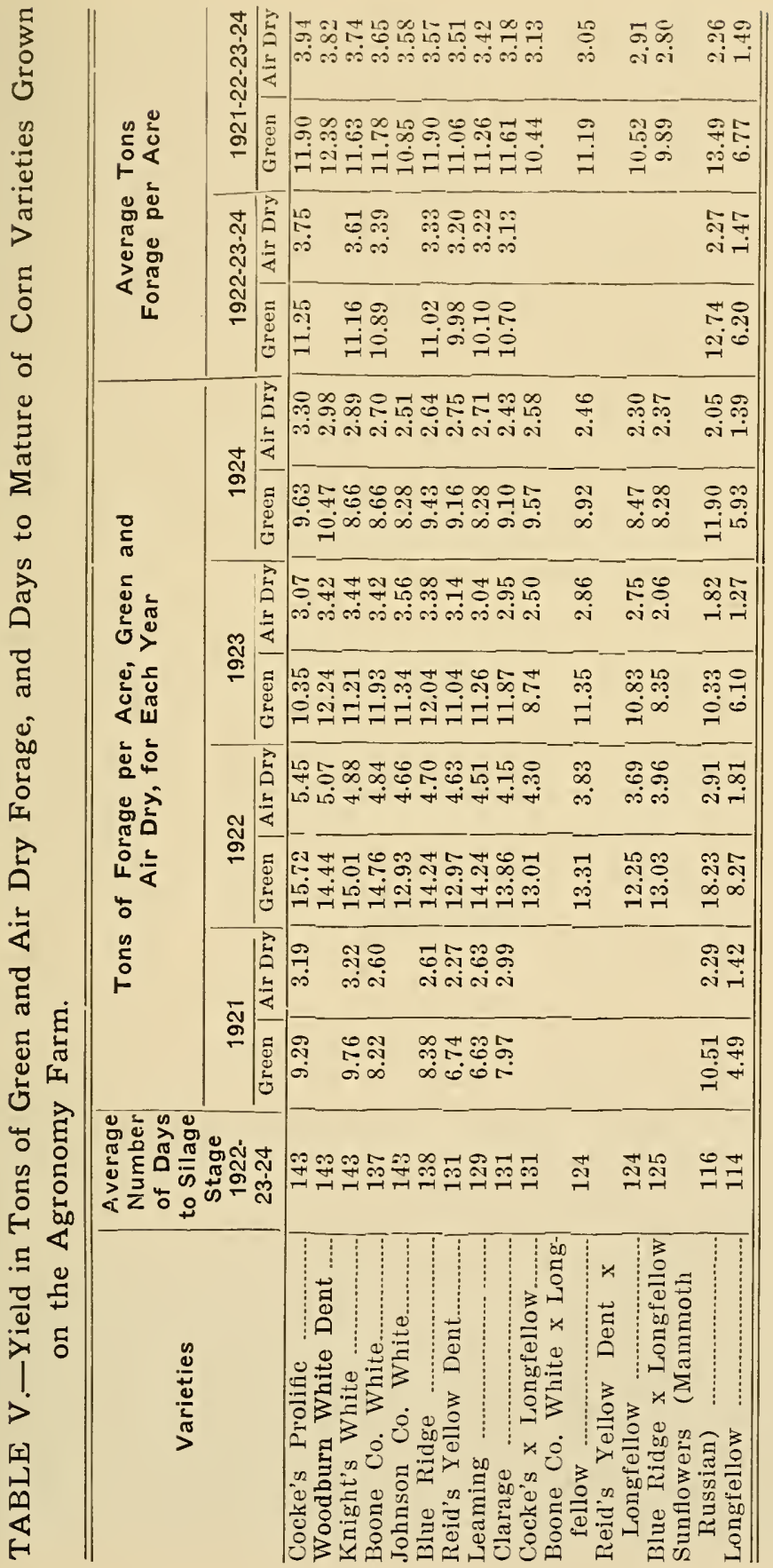


In the last column of Table $\mathrm{V}$ the average yields in tons per acre of air dry forage of the several varieties for the years 1922 to 1924, inclusive, are shown. Cocke's Prolific, Woodburn White Dent, Knight's White, and Boone County White rank first, second, third, and fourth, respectively, with regard to average yield. Anyone of these varieties may be expected to produce a satisfactory tonnage under conditions similar to those under which they were grown. Longfellow flint and Mammoth Russian Sunflowers rank last and next to last with respect to average yield. The first generation crosses yielded less than their dent parents but matured considerably earlier. In the third column from the right of the table the average yield in tons of air dry forage of the varieties which were grown for four years are listed. The relative rank of the varieties on the basis of a four-year-average yield is practically the same as on the basis of a three-year-average yield.

In next to the last column the average yields in tons per acre of green forage are listed. In general, the yields on this basis correspond roughly to the yields on an air dry basis but there is one notable exception, namely, Mammoth Russian sunflowers. Although the sunflowers produced on the average the greatest tonnage of green material they rank near the bottom in tonnage of air dry forage. Of the several corn varieties Woodburn White Dent ranks first on the basis of average green weight but there are several varieties which do not differ significantly from it in this respect.

In choosing a variety of corn which is to be grown for the silo it is important to consider not only gross tonnage from the standpoint of both green and air dry material but also to consider the feeding value per acre. This may best be done by suitable feeding experiments. However, in the absence of such expriments a chemical analysis of the silage may be fairly indicative of relative value.

It has been mentioned above that a sample of the green forage of each of the fifteen varieties grown in this experiment was firmly tamped into two-quart Mason jars and later analyzed. When the samples preserved in this way were analyzed they could not be distinguished from ordinary silage.* The percentage of protein, fat, 
and carbohydrates based on the air dry silage were multiplied by the yields of air dry forage (Table V) to obtain the yields of the nutrients per acre. The results are presented in Table V'T.

In the first column of Table VI the varieties are listed according to rank with respect to their total average production of protein, fat, and nitrogen free extract, which is shown in the last column of the table. It will be noted that the rank of the varieties with respect to the arerage annual production of these three nutrients corresponds roughly with the rank of the varieties with respect to the average yield of air dry forage (Table V). In both tables Cooke's Prolific, Woodburn White Dent, Knight's White, Boone County White and Johnson County. White occupy the first five places, although the order of the varieties is not the same in both tables.

With respect to arerage production of protein in pounds per acre, as shown in the fifth column of Table VI, Cocke's Prolific, Woodburn White Dent, Johnson County White, and Leaming were the highest yielders. Sunflowers produced the highest yield of fat, as shown in the ninth column of this table. Johnson County White and Cocke's Prolific each produced on the arerage 213.7 pounds of fat per acre, which was 31.6 pounds less than that produced by the sunflowers. The average yield in pounds of nitrogen free extract (sixth column from the right) corresponds closely to the total average yield of the three most important nutrients (last column). Cocke's Prolific produced a considerably higher average yield of fiber than any other variety (next to last column). The sunflowers produced relatively more fiber in proportion to the yield of air dry forage than was produced by any of the varieties of corn.

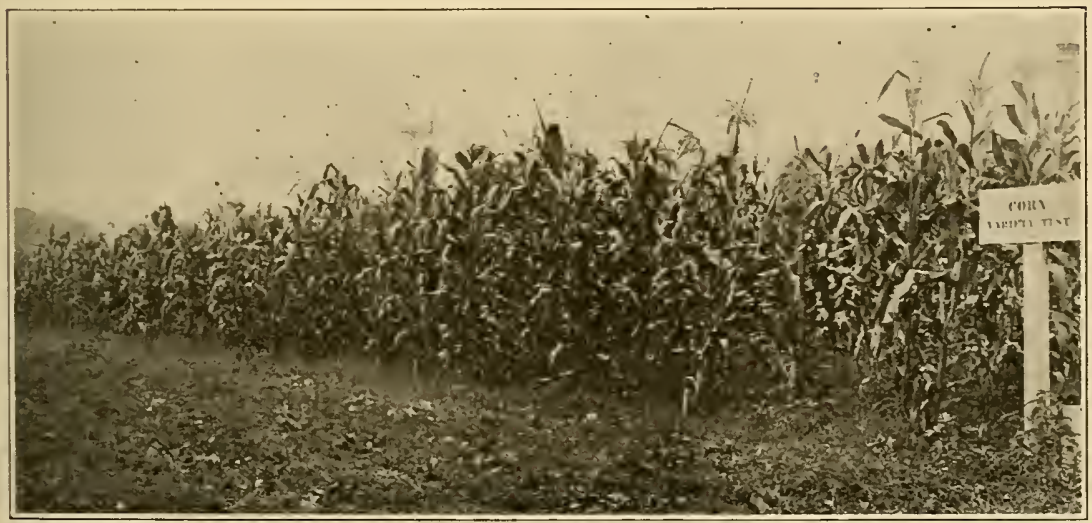




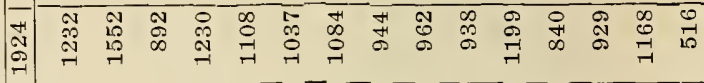

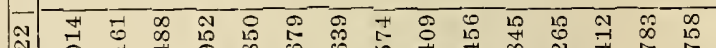
ब 2 ล

勇 齐

돗

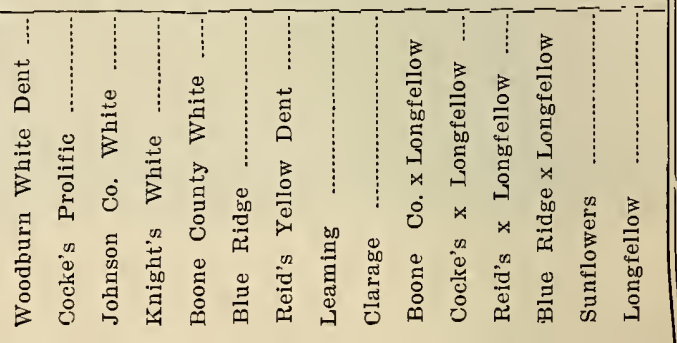




\section{EXPERIMENTS AT THE MAGGIE SUBSTATION}

The Maggie Substation is located near the Ohio River in Mason County. The varietal experiments here, which were carried on for two years only, were located on first bottom land that is highly productive. The growing season is somewhat longer at Maggie than at Morgantown and for this reason relatively later maturing varieties may be grown. The varieties which were included in the test and their yields are shown in Table VII.

\section{TABLE VII.-Yield Per Acre in Bushels of Shelled Corn of Varie- ties Grown at the Maggie Substation.*}

\begin{tabular}{|c|c|c|c|}
\hline \multirow[t]{2}{*}{ Varieties $\dagger$} & \multicolumn{2}{|c|}{$\begin{array}{c}\text { Yield Per Acre in } \\
\text { Bushels }\end{array}$} & \multirow{2}{*}{$\begin{array}{c}\text { Average } \\
\text { Yield in } \\
\text { Bushels, } \\
1922-23\end{array}$} \\
\hline & $1922 \div$ & 1923⿱亠巾口十 & \\
\hline Woodburn White Dent & \multirow{8}{*}{$\begin{array}{l}88.3 \\
80.7 \\
80.0 \\
76.8 \\
76.4 \\
67.1 \\
75.2 \\
\ldots . . .\end{array}$} & \multirow{7}{*}{$\begin{array}{l}92.5 \\
79.4 \\
72.6 \\
75.7 \\
73.9 \\
76.3\end{array}$} & 90.4 \\
\hline Boone County White ......... & & & 80.1 \\
\hline Golden Beauty (local) ... & & & 76.3 \\
\hline Reid's Yellow Dent & & & 76.3 \\
\hline 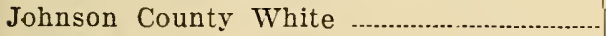 & & & 75.2 \\
\hline Leaming & & & 71.7 \\
\hline Success (local) & & & ...... \\
\hline Leaming $\mathrm{x}$ Longfellow & & 59.1 & -..... \\
\hline
\end{tabular}

* All yields calculated on air dry basis.

$¥$ Yields based on the average of five plots.

tGolden Beauty obtained from C. W. Brown; Success obtained from L. N. Knight.

Woodburn White Dent or U. S. Selection No. 77 yielded in 1922 7.6 bushels and in 192313.1 bushels more than Boone County White, the second highest yielding variety during the two years respectively. In view of the fact that the yields of the two varieties in each of the two years the experiment was carried on are based on the average of five plots and the further fact that a rather marked difference in yield was obtained, it seems reasonable to attach some s.ignificance to the results.

It will be recalled that the seed of Woodburn White Dent was obtained from Mr. J. M. Brown, Piketon, Ohio (Table II), where it was grown under conditions very similar to those which are found at Maggie. This fact undoubtedly accounts at least partially for the superiority in yield of this variety over some of those listed in Table VII, but it does not account for the difference in yield between Woodburn White Dent and Golden Beauty. Golden Beauty had been grown in the vicinity of the Maggie Substation for a number 
of years and was considered a high yielding variety of corn. Although the data on yield of the several varieties in the test cover a two-year period only, they indicate that Woodburn White Dent possesses a yielding capacity, for the particular conditions, greater than any other variety in the experiment

\section{EXPERIMENTS IN BERKELEY COUNTY}

In Berkeley County there were two co-operative varietal experiments--one on the farm of Mr. C. F. Hammond and the other on the farm of Mr. A. H. Stuckey. Both of these experiments were carried on during 1922 to 1924 inclusive.

In Table VIII. are listed the seven varieties of corn which were included in the test on the Hammond Farm. The varieties with the word "local" after them were obtained in the locality where the experiment was conducted. Seed of the other varieties was obtained from the sources already mentioned.

TABLE VIII.-Yield Per Acre in Bushels of Shelled Corn of Varieties Grown on the Hammond Farm in Berkeley County.

\begin{tabular}{|c|c|c|c|c|}
\hline \multirow{2}{*}{ Varieties* } & \multicolumn{3}{|c|}{ Yield Per Acre in Busheis } & \multirow{2}{*}{$\begin{array}{c}\text { Average } \\
\text { Yield in } \\
\text { Bushels, } \\
1922-23-24\end{array}$} \\
\hline & 1922 & 1923 & 1924 & \\
\hline Leaming (local) & 66.1 & 58.5 & 46.5 & 57.0 \\
\hline Leaming ….................. & 61.7 & 53.0 & 45.6 & 53.4 \\
\hline Boone County White & 65.4 & 53.8 & 39.7 & 53.0 \\
\hline Reid's Yellow Dent & 60.9 & 57.0 & 40.2 & 52.7 \\
\hline Reid's Yellow Dent (local) & 61.1 & 58.2 & 38.1 & 52.5 \\
\hline Boone County White (local).. & 62.1 & 53.0 & 41.1 & 52.1 \\
\hline Johnson County White ............ & 61.8 & 55.9 & 33.0 & 50.2 \\
\hline
\end{tabular}

*Leaming (local) obtained from C. F. Hammond; Reid's Yellow Dent (locai) cbtained from H. L. Smith; Boone County White (local) obtained from T. H. Wilson.

In the last column of Table VIII the average yields in bushels of shelled corn per acre are shown. There is a difference between the average yields of the highest and lowest producing sorts of only 6.8 bushels. The local strain of Leaming, which ranked the highest in the test, has been grown by Mr. Hammond for several years. It yielded on the average 3.6 bushels more than the other strain of Leaming. Moreover, the second, third, and fourth columns show that the difference in yield between these two strains is fairly consistent throughout the three years of the experiment. According 
to Students' Method (see appendix) of analyzing results such as these the chances are about 15 to 1 that the difference in yield between the two strains of Leaming is truly significant. In other words the chances are 15 to 1 that the difference in yield obtained here is owing to a real difference in the inherent yielding capacity of the two varieties when grown under this particular environment and not owing solely to chance or accident. The average yields of the two strains of Reid's Yellow Dent do not differ significantly. The relatively low average yield of Johnson County White is owing largely to the low yield produced by this variety in 1924 (fourth column.) The season of 1924 was rather adverse for late maturing varieties of corn such as Johnson County White.

The experiment on the Stuckey farm included the same varieties that were grown on the Hammond farm with the addition of a fourth local variety, Blue Dent. The varieties and yields are shown in Table IX.

TABLE IX.-Yield Per Acre in Bushels of Shelled Corn of Varieties Grown on the Stuckey Farm in Berkeley County.

\begin{tabular}{|c|c|c|c|c|}
\hline \multirow{2}{*}{ Varieties* } & \multicolumn{3}{|c|}{ Yield Per Acre in Bushels } & \multirow{2}{*}{$\begin{array}{l}\text { Average } \\
\text { Yield in } \\
\text { Bushels, } \\
1922-23-24\end{array}$} \\
\hline & 1922 & 1923 & 1924 & \\
\hline Leaming (local) & 40.2 & 38.6 & 22.4 & 33.7 \\
\hline Boone County White ............... & 35.7 & 44.7 & 18.7 & 33.0 \\
\hline Leaming & 34.7 & 39.9 & 22.0 & 32.2 \\
\hline Reid's Yellow Dent & 29.5 & 44.1 & 20.2 & 31.3 \\
\hline Boone County White (local)... & 35.2 & 41.6 & 15.9 & 30.9 \\
\hline Johnson County White ......... & 34.2 & 44.3 & 13.7 & 30.7 \\
\hline Blue Dent (local & 37.1 & 32.7 & 21.4 & 30.4 \\
\hline Reid's Yellow Dent (local) & 30.4 & 39.9 & 20.2 & 30.2 \\
\hline
\end{tabular}

*Leaming (local) obtained from C. F. Hammond; Reid's Yellow Dent (local) obtained from H. L. Smith; Boone County White (local) obtained from T. H. Wilson; Blue Dent obtained from A. H. Stuckey.

The yields given in the last column of Table IX show an extreme difference of only 3.5 bushels between the variety (local Leaming), which produced the highest, and the one (local Reid's Yellow Dent), which produced the lowest average yield of shelled corn per acre during the three years 1922 to 1924, inclusive. This difference is not significant. It is interesting to note that on the basis of average yield the local strain of Leaming again ranks first. An examination of the second, third, and fourth columns shows that the yields in any one year were quite variable and also that the relative yields of the varieties from year to year were not very consistent. 


\section{EXPERIMENTS IN HARDY COUNTY}

The varietal test in Hardy County was carried on for two years only. The work was done on the Reymann Memorial Farm near Wardensville and under the immediate direction of Mr. L. F. Sutton, superintendent of the farm. The varieties and yields are recorded in Table X.

TABLE X.-Yield Per Acre in Bushels of Shelled Corn of Varieties Grown on the Reymann Memorial Farm in Hardy County.

\begin{tabular}{|c|c|c|c|}
\hline \multirow[t]{2}{*}{ Varieties* } & \multicolumn{2}{|c|}{$\begin{array}{c}\text { Yield Per Acre in } \\
\text { Bushels }\end{array}$} & \multirow{2}{*}{$\begin{array}{l}\text { Average } \\
\text { Yield in } \\
\text { Bushels, } \\
1922-1923\end{array}$} \\
\hline & $1922 \dagger$ & $1923 \grave{⿱}$ & \\
\hline Johnson County White . & 55.7 & 50.5 & 53.1 \\
\hline Boone County White. & 55.2 & 46.4 & 50.8 \\
\hline 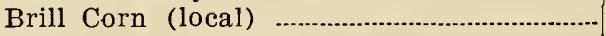 & 53.4 & 40.5 & 47.0 \\
\hline Reid's Yellow Dent ...... & 49.1 & 39.3 & 44.2 \\
\hline Leaming .. & 43.4 & 43.3 & 43.4 \\
\hline Cocke's Prolific & 43.4 & 35.9 & 39.7 \\
\hline Boone County White $\mathrm{x}$ Longfellow.......... & 41.4 & 36.7 & 39.1 \\
\hline Leaming $x$ Longfellow & 34.7 & 33.8 & 34.3 \\
\hline Longfellow ... & 10.4 & 11.5 & 11.0 \\
\hline Silver King & ....... & 41.2 & -..... \\
\hline Yellow Cap Red (local) & ....... & 41.7 & ...... \\
\hline
\end{tabular}

†Yield of each plot based on one central row only.

YYield of each variety based on a single plot only.

*Brill corn (local) obtained from Brill Bros; Reid's Yellow Dent (local) obtained from Reymann Memorial Farm; Yellow Cap Red (local) obtained from Winchester Seed Corporation.

Owing to local conditions it was found necessary to modify the original plan of the experiment. In 1922 the yield of each variety was based on the average yield of four central rows from as many plots, one row from each plot. The year following the yield was based on two central rows of a single plot only. In view of these facts the results of this experiment are not very trustworthy. It is interesting to note, however, that the yields in 1922 (second column of Table X) and in 1923 (third column) are fairly consistent as to relative rank.

\section{EXPERIMENTS IN GREENBRIER COUNTY}

During 1922 two varietal experiments were carried on in Greenbrier County, one on the farm of Mr. J. B. Sydenstricker and one on the farm of Mr. O. B. Humphreys. In 1923 and 1924 a varietal test was conducted on the Sydenstricker farm only. The varieties grown and the yields obtained are shown in Table XI. 
TABLE XI.-Yield Per Acre in Bushels of Shelled Corn of Varieties Grown on the J. B. Sydenstricker Farm in 1922, 1923, and 1924; and on the Humphrey Farm in 1922, Both in Greenbrier County.

\begin{tabular}{|c|c|c|c|c|c|}
\hline \multirow{2}{*}{ Varities* } & \multicolumn{3}{|c|}{ Yield Per Acre in Bushels } & \multirow{2}{*}{$\begin{array}{c}\text { Average } \\
\text { Yield in } \\
\text { Bushels, } \\
1922-23-24\end{array}$} & \multirow{2}{*}{$\begin{array}{l}\text { Yield } \\
1922 \ddagger\end{array}$} \\
\hline & 1922 & $1923 \dagger$ & 1924 & & \\
\hline Local Yellow ... & 55.1 & 53.9 & 14.1 & 41.0 & 50.7 \\
\hline Leaming .............. & 44.4 & 52.3 & 15.0 & 37.2 & 49.8 \\
\hline Local White & 51.4 & 48.0 & 10.3 & 36.6 & 48.4 \\
\hline Reid's Yellow Dent ......... & 52.7 & 43.0 & 6.5 & 34.1 & 44.8 \\
\hline Silver King ................................... & 44.0 & 45.1 & 11.6 & 33.6 & 39.1 \\
\hline Clarage $\mathrm{x}$ Longfellow & 39.1 & 45.5 & 15.0 & 33.2 & 38.2 \\
\hline Leaming $x$ Longfellow ....... & 38.4 & 47.5 & 11.9 & 32.6 & 34.3 \\
\hline Clarage & 36.9 & 38.4 & 7.6 & 27.6 & 34.3 \\
\hline Longfellow .. & 7.9 & 16.5 & 9.3 & 11.2 & 11.8 \\
\hline
\end{tabular}

†In 1923 plots were 105 feet long.

†ields obtained on the Humphrey farm.
$*$ Local Yellow obtained from C. W. Handley in 1922 and R. A. Anderson in 1923 and 1924. Local White obtained from C. W. Handley in 1922 and $\mathrm{S}$. W. Anderson in 1923 and 1924.

In next to the last column of Table XI the average yield in bushels of shelled corn per acre for the varieties grown on the Sydenstricker farm are shown. Local Yellow, Leaming, and Local White gave the highest average yields. According to Students' Method the difference in yield between Local Yellow and Local White is probably significant but between Local Yellow and Leaming the difference, in yield is not significant. The average yield of the first generation cross, Clarage crossed with Longfellow, is 5.6 bushels greater than Clarage, the dent parent, and 22 bushels greater than Longfellow, the flint parent. The chances are about 24 to 1 that the former difference is significant. Here is an instance of a first generation cross that seems to possess greater yielding capacity than either of its parents.

In the last column of the table the average yields of the varieties grown on the Humphrey Farm in 1922 are shown. The four varieties, Local Yellow, Leaming, Local White, and Reid's Yellow Dent, which produced the highest average yields here, also produced the highest average yields on the Sydenstricker Farm during the same year (second column). 


\section{EXPERIMENTS IN MERCER COUNTY}

The environmental conditions for the production of corn in Mercer County are somewhat similar to those of Greenbrier County. In view of this fact the same varieties were tested in both counties. The results of the work in Mercer County are recorded in Table XII.

The test was conducted on a different farm each year and for this reason the averages presented in fifth and sixth columns are not very trustworthy. The average yields in 1922 (second column) and in 1924 (fourth column) are based on the total production of all four rows of each plot, instead of on the two central rows as in most of the varietal experiments.

\section{TABLE XII.-Yield Per Acre in Bushels of Shelled Corn of Varie- ties Grown on the County Farm in 1922, on the Bowl- ing Farm in 1923, and on the Belcher Farm in 1924, All in Mercer County.}

\begin{tabular}{|c|c|c|c|c|c|}
\hline \multirow{2}{*}{ Varieties* } & \multicolumn{3}{|c|}{ Yield Per Acre in Bushels } & \multirow{2}{*}{$\begin{array}{l}\text { Average } \\
\text { Yield in } \\
\text { Bushels, } \\
1922-1923\end{array}$} & \multirow{2}{*}{$\begin{array}{c}\text { Average } \\
\text { Yield in } \\
\text { Bushels, } \\
1922-23-24\end{array}$} \\
\hline & $1922 \dagger$ & 1923 & $1924 \grave{\dagger}$ & & \\
\hline Silver King & 41.2 & 48.2 & 32.0 & 44.7 & 40.5 \\
\hline Leaming ... & 36.4 & 44.3 & $\cdots$ & 40.4 & 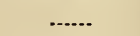 \\
\hline Reid's Yellow Dent & 38.6 & 41.9 & & 40.3 & \\
\hline Clarage $\mathrm{x}$ Longfellow... & 38.8 & 41.4 & 38.4 & 40.1 & 39.5 \\
\hline 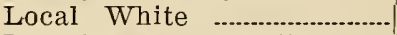 & 37.8 & 41.9 & 44.0 & 39.9 & 41.2 \\
\hline Leaming $x$ Longfellow.... & 37.6 & 41.5 & 35.4 & 39.6 & 38.2 \\
\hline 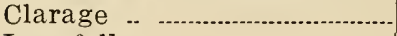 & 34.2 & 34.7 & $\cdots$ & 34.5 & ....... \\
\hline Longfellow .. & 26.6 & 21.0 & 27.7 & 23.8 & 25.1 \\
\hline Local Yellow & -.....- & 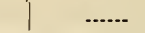 & 39.9 & -..-- & ....... \\
\hline
\end{tabular}

* Local Yellow obtained from W. P. Winfrey; Local White obtained from L. J. Belcher. $\dagger$ Yield of each plot based on all four rows instead of the two central rows only.

An examination of Table XII shows that Silver King, an early maturing white dent corn, yielded consistently high on both the County Farm in 1922 and the farm of Mr. O. H. Bowling in 1923, but produced a relatively low yield the next year on the farm of $\mathrm{Mr}$. L. J. Belcher. In the test at the last named place (fourth column), Local White, Local Yellow, and Clarage crossed with Longfellow were the three highest yielders. In general, the results of the varietal experiments in 1922 and 1923 agree with each other more closely than they do with the results of 1924 . It will be recalled that the season of 1924 was not favorable to corn production. In this year the Reid's Yellow Dent, Leaming, and Clarage did not mature and were not harvested. 
In the fifth column may be found the average yield of the varieties grown in 1922 and 1923. Of the eight varieties grown during this time, six produced satisfactory average yields. The extreme difference between the average yields of these six varieties is 5.1 bushels. According to Students' Method the odds are about 10 to 1 that this difference is significant. The average yield of Clarage crossed with Longfellow exceeded that of Clarage by 5.6 bushels. Although this difference is based on a two-year average only, it is rather significant that in this experiment as well as the one in Greenbrier County, the first generation cross exceeded the yield of either of its parents.

\section{EXPERIMENTS IN BROOKE COUNTY}

The varietal tests in Brooke County were carried on for two years only; in 1922 on the farm of Mr. W. H. Sill and in 1923 on the iarm of Mr. Will Finley. The yields of the varieties grown are recorded in Table XIII.

\section{TABLE XIII.-Yield Per Acre in Bushels of Shelled Corn of Varie- ties Grown on the Sill Farm in 1922, and on the Finley Farm in 1923, Both in Brooke County.}

\begin{tabular}{|c|c|c|c|}
\hline \multirow[t]{2}{*}{ Varieties* } & \multicolumn{2}{|c|}{$\begin{array}{c}\text { Yield Per Acre in } \\
\text { Bushels }\end{array}$} & \multirow{2}{*}{$\begin{array}{c}\text { Average } \\
\text { Yield in } \\
\text { Bushels, } \\
1922-23\end{array}$} \\
\hline & 1922 & 1923 & \\
\hline Hybrid Yellow Dent (local) ..... & 53.3 & 54.1 & 53.7 \\
\hline Red Top Yellow Dent (local) & 51.1 & 50.7 & 50.9 \\
\hline Reid's Yellow Dent (local) .... & 49.3 & 50.7 & 50.0 \\
\hline 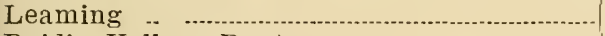 & 49.1 & 49.2 & 49.2 \\
\hline 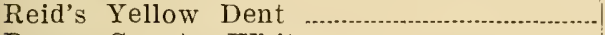 & 45.8 & $50.7 \dagger$ & 48.3 \\
\hline Boone County White & 50.6 & 36.7 & 43.7 \\
\hline Johnson County White & 48.3 & 36.6 & 42.5 \\
\hline
\end{tabular}

*Hybrid Yellow Dent obtained from J. T. Burge; Red Top Yellow Dent obtained from W. H. Sill; Reid's Yellow Dent local obtained from S. C. Gist, Jr.

$\dagger$ Yield based on the average of three plots only.

An examination of the second and third columns of Table XIII shows that the yields for the two-year period are fairly consistent. The three local sorts were among the highest yielding varieties each year. This fact is also shown by the average yields listed in the fourth column. The three local varieties produced an average of 53.7, 50.9 , and 50.0 bushels of shelled corn per acre, whereas Reid's Yellow Dent and Leaming gave average yields of 49.2 and 48.3 bushels 
respectively. The differences in average yield between these five varieties are not very significant in view of the fact that they are based on tests carried on for two years only. Boone County White and Johnson County White failed to mature in 1923, which fact accounts for the relatively low yields in that year.

\section{EXPERIMENTS IN RANDOLPH COUNTY}

The altitude of most of the farm land in Randolph County is relatively high and therefore not adapted to growing late maturing corn. The varietal experiments in this county were carried on for three years on the County Farm. The varieties grown and yields obtained are listed in Tablc XIV.

TABLE XIV.-Yields Per Acre in Bushels of Shelled Corn, of Varieties Grown on the County Farm in Randolph County.

\begin{tabular}{|c|c|c|c|c|}
\hline \multirow{2}{*}{ Varieties* } & \multicolumn{3}{|c|}{ Yield Per Acre in Bushels } & \multirow{2}{*}{$\begin{array}{c}\text { Average } \\
\text { Yield in } \\
\text { Bushels, } \\
1922-23-24\end{array}$} \\
\hline & 1922 & $1923 \dagger$ & $1924 \dagger$ & \\
\hline Silver King & \multirow{9}{*}{$\begin{array}{c}64.4 \\
57.2 \\
50.8 \\
56.4 \\
46.6 \\
51.5 \\
57.8 \\
22.7\end{array}$} & \multirow{8}{*}{$\begin{array}{l}39.4 \\
41.9 \\
47.1 \\
43.5 \\
31.9 \\
43.1 \\
34.7 \\
18.4+\end{array}$} & \multirow{8}{*}{$\begin{array}{l}44.2 \\
47.0 \\
45.3 \\
41.0 \\
49.9 \\
33.3+ \\
25.4+\end{array}$} & \multirow{8}{*}{$\begin{array}{l}49.3 \\
48.7 \\
47.7 \\
47.0 \\
42.8 \\
42.6 \\
39.3\end{array}$} \\
\hline Golden Glow & & & & \\
\hline Shoe Peg (local)................. & & & & \\
\hline Golden Glow x Longfellow.... & & & & \\
\hline Minnesota No. 13 & & & & \\
\hline Clarage $\mathrm{x}$ Longfellow.................. & & & & \\
\hline Clarage & & & & \\
\hline Longfellow & & & & \\
\hline Crawford White Dent (local) & & ....... & 40.8 & ....... \\
\hline
\end{tabular}

* Shoe Peg obtained from County Farm; Crawford White Dent obtained from Herbert Crawford.

TYield of each plot based on all four rows instead of the two central rows only.

Yield based on the average of three plots only.

The second, third, and fourth columns of Table XIV show that the relative rank of the several varieties with regard to yield is not consistent. The highest yielders in 1922 were Silver King, Clarage, and Golden Glow; in 1923 Shoe Peg and Golden Glow crossed with Longfellow, and in 1924 Minnesota No. 13, Golden Glow, and Shoe Peg. The two varieties last named are the only ones that were among the three highest yielding varieties in two out of the three years the test was carried on. For the above reasons the average yields in the fifth column are not very trustworthy. It is interesting to note that the first generation cross (Clarage $x$ Longfellow) again exceeded the average yield of its higher yielding parent (Clarage) by 3.3 bushels. 


\section{SUMMARY}

1.-Corn varictal experiments were carried on from two to four years on the Agronomy Farm near Morgantown and in the following counties: Mason, Berkeley, Iardy, Greenbrier, Mercer, Randolph, and Brooks.

2.-On the Agronomy Farm, Leaming, Reid's Yellow Dent, Woodburn White Dent (U. S. Selection No. 77), and Boone County White produced the highest average yields of shelled corn per acre, whereas Cocke's Prolific Woodburn White Dent, Knight's White, and Boone County White produced the highest average yields of air dry forage (cut at the "ear-glazed" stage) per acre. On the basis of the four-year-average yield of air dry forage, Leaming and Reid's Yellow Dent produced approximately one-half ton per acre less than Cocke's Prolific, the highest yielding variety.

3.-The first generation crosses between Longfellow flint and certain dent varieties grown on the Agronomy Farm, in general, yielded both in grain and air dry forage somewhat less than their respective dent parents but matured somewhat earlier.

4.-Mammoth Russian sunflowers on the Agronomy Farm produced the highest average yield per acre of green forage, but on the basis of air dry forage the average yield was next to the lowest of all the varieties in the test. Longfellow flint corn produced less air dry forage per acre than was produced by the sunflowers.

5.- The total average yields of protein, fat, and nitrogen freeextract of the several varieties grown on the Agronomy Farm correspond approximately to the average yields of the air dry forage. The sunflowers produced relatively more fat and crude fiber in proportion to the amount of dry forage than was produced by any of the varieties of corn.

6.-At the Maggie Substation, Woodburn White Dent (U. S. Selection No. 77), on the basis of a two-year average yield, produced 10.3 bushels per acre more than any other variety in the test.

7.-The results of the co-operative varietal experiments show in general that local high yielding varieties or strains of corn produce as well as, and sometimes better than, high yielding varieties or strains introduced from elsewhere. 
8.-The experiments in Berkeley County did not reveal any striking differences in average yields between any of the varieties in the tests. Two strains of Leaming and one each of Boone County White and Reid's Yellow Dent produced the highest average yields of shelled corn per acre on both the Hammond and Stuckey farms.

9.-In Greenbrier County a local yellow strain, a local white strain, and the Leaming variety obtained from Mr. George S. Strosnider near Waynesburg, Pennsylvania, produced the highest average yields of shelled corn per acre.

10.-The variety Silver King, which is a white dent corn, produced the highest yield of grain in both 1922 and 1923 in the experiments in Mercer County.

11.- In Randolph County the varieties Silver King, Golden Glow, and Shoe Peg, and the first generation cross of Golden Glow and Longfellow all produced satisfactory yields of grain.

12.-In Brooke County the three local strains of corn produced the highest average yields of grain. The introduced strains of Leaming and Reid's Yellow Dent, however, did not produce significantly lower yields than the local strains.

13.- Johnson County White, Boone County White, and Brill Corn produced the highest average yields of shelled corn in the varietal experiments on the Reymann Memorial Farm in Hardy County.

14. - The first generation cross of Clarage and Longfellow produced a higher average yield of shelled corn per acre than either of its parents in the three counties where they were compared, namely, Greenbrier, Mercer, and Randolph. 


\section{APPENDIX}

During the last few years considerable has been written concerning the advantages and disadvantages of the probable error in interpreting field experiments. At present most agronomists use this criterion in some form as an aid in determining the significance of yield obtained in plot experimentation. Much of the adverse criticism that has been aimed at the probable error concept is owing to the lack of sympathetic understanding and an appreciation of its true value. The statistical method of analysis as an end in itself is of no particular interest to the agronomist, but as an aid in interpreting results of field experiments it becomes of great importance.

One of the greatest advantages of the statistical method of anal$y$ sis is that it tends to remove the "personal equation" from the interpretation of experimental results. What may seem like a significant difference to one investigator may not seem so to another. One has only to examine the pages of a few bulletins presenting the restults of agricultural experiments to be convinced of this fact.

While it is true that there are instances in the agricultural literature where the particular use that has been made of the probable error is questionable, it is true also that there are many more instances where the use of the probable error would have prevented the deduction of erroneous conclusions. A statistically significant difference cannot mean more than the data on which it is based. If the particular method used in determining the significance of the difference has been wrongly applied, that is the fault of the investigator and not of the method. Experimental results should be analyzed in such a way as to insure reaching the most trustworthy conclusions. Any method which reduces the amount of "guessing" to a minimum is justified.

In field experiments such as varietal trials the investigator is frequently confronted with the necessity of using a small number of plots and of carrying on the work for a few years only. The fundamental principles of the statistical method of analysis are based on large numbers of variables, for it is only when there are large numbers available that the laws of chance have a fair opportunity to operate. There are, however, several methods of analysis which have been evolved for relatively small numbers of variables. Even with these special methods there is always an element of danger in applying them rigidly when few individuals or varieties are involved. One of the special methods which possesses several advantages, and 
which is meeting with considerable favor among agronomists, is that suggested by Student a number of years ago.* This method has been used in interpreting the results presented in this bulletin. The reader is referred to the literature cited for a discussion of the method, as illustrations of its use only will be presented here.

Suppose that it is desired to determine the significance of the difference in yield of bushels of shelled corn per acre between Leaming and Reid's Yellow Dent corn grown on the Agronomy Farm (Table III). We proceed as follows:

\begin{tabular}{|c|c|c|c|c|}
\hline Yields of Leaming & $\begin{array}{r}1921 \\
45.9\end{array}$ & $\begin{array}{c}1922 \\
71.3\end{array}$ & $\begin{array}{c}1923 \\
59.8\end{array}$ & $\begin{array}{r}1924 \\
41.9\end{array}$ \\
\hline Yields of Reid's Yel. Dent........................... & 45.8 & 83.0 & 46.1 & 36.4 \\
\hline Algebraic differences & +0.1 & -11.7 & +13.7 & +5.5 \\
\hline $\begin{array}{l}\text { Mean difference. } \\
\text { Standard deviation of differences.. }\end{array}$ & & & & \\
\hline
\end{tabular}

Divide the mean by the standard deviation, which gives the value of $\mathrm{Z}(1.9 / 9.2=0.21)$. Now looking up the odds in Love's tables (modified form of Student's table) corresponding to $Z=0.21$ and under $\mathrm{n}=4$, we find by interpolation that they are approximately 1.7 to 1 . In other words, the chances are only 1.7 to 1 that the difference between these two varieties is owing to an inherent difference in their yielding capacity for the particular conditions. From this we conclude that the difference in average yield between the two varieties in this experiment is not significant.

In a similar manner it is possible to determine the significance of the difference in yield in tons of air dry forage (Table V.) between Cocke's Prolific and Blue Ridge. Proceeding as before we find the odds are about 10 to 1 . The chances are 10 to 1 that for the given conditions Cocke's Prolific possesses greater yielding capacity than Blue Ridge.

* See references to Student's Method in Literature Cited at end of this bulletin.

$\dagger$ In computing standard deviation the following formula was used: Standard deviation $=\sqrt{\frac{\mathrm{fd}^{2}}{n}}$ 


\section{LITERATURE CITED}

LOVE, H. H., and BRUNSON, A. M.

1924. STUDENT'S METHOD FOR INTERPRETING PAIRED EXPERIMENTS. Jour. Amer. Soc. Agron. 16:60-68.

LOVE, H. H.

1924. A MODIFICATION OF STUDENT'S TABLE FOR USE IN INTERPRETING EXPERIMENTAL RESULTS. Jour. Amer. Soc. Agron. 16:68-73.

SALMON, S. C.

1924. SOME MISAPPLICATIONS AND LIMITATIONS IN USING STUDENT'S METHOD TO INTERPRET FIELD EXPERIMENTS. Jour. Amer. Soc. Agron. 16:717-721.

STUDENT

1908. THE PROBABLE ERROR OF A MEAN. Biometrika 6:1-12.

1915-17. TABLES FOR ESTIMATING PROBABILITIES BASED ON SMALL SAMPLES. Biometrika 11:414-417. 





\section{HECKMAN}

BINDERY INC.

\section{JUNE 99}

Bound -To-Please N. MANCHESTER 
